BMJ Paediatrics Open

\section{Advancing child nutrition science in the scaling up nutrition era: a systematic scoping review of stunting research in Guatemala}

To cite: Cordon A, Asturias G, De Vries T, et al. Advancing child nutrition science in the scaling up nutrition era: a systematic scoping review of stunting research in Guatemala. BMJ Paediatrics Open 2019;3:e000571. doi:10.1136/ bmjpo-2019-000571

- Additional material is published online only. To view please visit the journal online (http://dx.doi.org/10.1136/ bmjpo-2019-000571).

Received 23 August 2019 Revised 17 October 2019 Accepted 22 November 2019

Check for updates

(c) Author(s) (or their employer(s)) 2019. Re-use permitted under CC BY-NC. No commercial re-use. See rights and permissions. Published by BMJ.

${ }^{1}$ Centre for Research in Indigenous Health, Wuqu' Kawoc I Maya Health Alliance, Tecpán, Chimaltenango, Guatemala ${ }^{2}$ Centre for Evidence-Based Development, Fundación Desarrolla Guatemala para la Educación y Salud (FUNDEGUA), Guatemala City, Guatemala ${ }^{3}$ Division of Global Health Equity, Brigham and Women's Hospital, Boston, Massachusetts, USA

Correspondence to Dr Peter Rohloff; prohloff@bwh. harvard.edu

\section{ABSTRACT}

Introduction Ever since the 1960s, Guatemala has been a principle site for global academic research on child growth and nutrition. Nevertheless, Guatemala still has one of the highest rates of child stunting in the world. Since 2012, Guatemala has had a comprehensive national policy on stunting, calling for a renewed investment in innovative, multilevel nutrition interventions and implementation science. Our objective was to perform a systematic search and scoping review of the literature on stunting in Guatemala to identify gaps in research and opportunities for responding to this unique policy opportunity.

Methods We conducted a systematic search and scoping review on stunting in Guatemala, searching the PubMed, Web of Science and PsycINF0 databases. Eligible articles were of any design or format, published in English and Spanish from 2000 to 2018. Articles were thematically grouped by those published before (2000-2011) and after (2012-2018) the new national policy initiatives.

Results We identified a total of 1934 articles through database searches. After full-text review, 104 were included in the synthesis. The volume of published articles on stunting increased from a mean of 3.2 to 9.4 articles/ year before and after 2012. There was a shift toward articles generating new data on priority populations, including rural indigenous Maya populations ( $34 \%$ vs $61 \%, \chi^{2}$ test, $\left.p=0.01\right)$. However, the proportion of studies conducting implementation evaluations or testing new interventions was low and did not change significantly $\left(34 \%\right.$ vs $18 \%, \chi^{2}$ test, $\left.p=0.07\right)$. Among 17 identified intervention studies, only 4 tested multilevel interventions, and there were no published interventions incorporating nutrition-sensitive interventions.

Conclusions A systematic search and scoping review of the literature on child stunting in Guatemala identified critical opportunities for new research in multilevel interventions, nutrition-sensitive interventions and implementation science.

\section{INTRODUCTION}

Stunting is the most common paediatric growth disorder in the world and is associated with an increased risk for developmental delay. Guatemala is a populous Central American country with one of the highest rates of stunting in the world, especially among its
What is known about this subject?

Stunting is one of the most important paediatric disorders worldwide, contributing to delayed development.

- Effective approaches to stunting require comprehensive, multilevel interventions addressing both direct and underlying mediators of child nutrition.

- The Scaling Up Nutrition framework calls for academic collaborations with policy-makers to help scale up stunting interventions.

What this study adds?

In a Guatemalan case study, there has been increasing scientific and academic interest in stunting since the adoption of the Scaling Up Nutrition framework.

- Despite the adoption of the framework, however, there have been few new studies of interventions addressing multiple determinants of child nutrition.

- Implementation science studies of scale-up efforts are few and more comprehensive evaluations are needed.

rural, indigenous Maya population. ${ }^{1}$ Within Central America, Guatemala has historically always shown the highest prevalence of stunting (figure 1). ${ }^{2}$

Guatemala has historically been a major site for global paediatric nutrition research. Many key insights into the long-term consequences of stunting have come from studies in Guatemala. For example, the Institute of Nutrition of Central America and Panama (INCAP) longitudinal study is one of the most important, most-cited and longest-running nutrition studies in the world. Begun in the 1960s, the INCAP study demonstrated for the world the importance of early child food supplementation and established the longterm cognitive, educational and economic benefits for these early childhood interventions. ${ }^{3}$ Other research from Guatemala has 


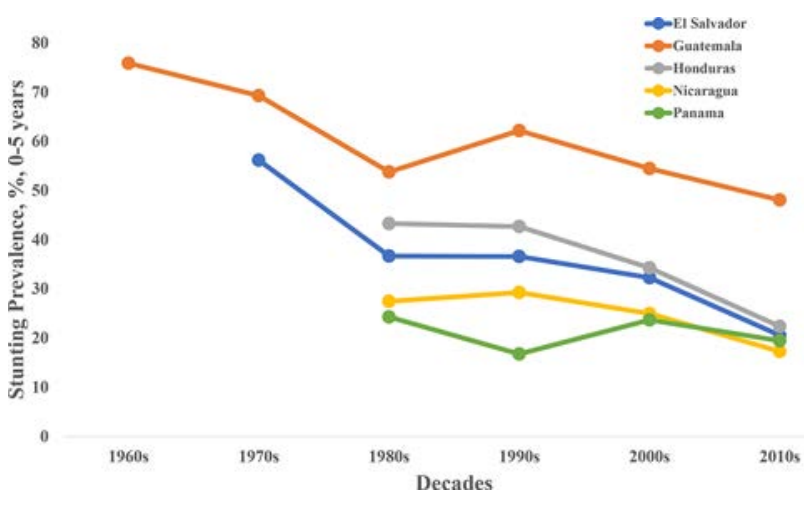

Figure 1 Prevalence of stunting in selected Central American countries by decade from the 1960s to 2010s. Point prevalence data drawn from national-level survey data for each decade from the WHO's Global Database on Child Growth and Malnutrition for Guatemala (orange line), Honduras (grey), El Salvador (blue), Nicaragua (yellow) and Panama (green).

included mapping of critical micronutrient deficiencies, the development of food fortification programme, early mass production of fortified complementary foods and exploration of the infection-nutrition paradigm. ${ }^{4-6}$

The publication of the WHO's Child Growth Standards in 2004 had a delayed but significant impact on political discourse about child health in Guatemala. ${ }^{7}$ The recognition that stunting was primarily driven by poverty and other social determinants, rather than genetics, led to calls for comprehensive, multisectorial action to improve child health. In 2005, the Guatemalan government ratified into law the National Food and Nutrition Security System (SINASAN in Spanish), which made food security a national right. This led to the development of official national strategies to address healthy nutrition and determinants of malnutrition, coordinated by the National Food and Nutrition Security Council (CONASAN in Spanish) and the Secretariat of Food and Nutrition Security (SESAN in Spanish). ${ }^{8}$ Initially, however, these policies were largely strategic and symbolic. However, Guatemala was an early signatory of the global Scaling Up Nutrition initiative and, beginning with the 2012 presidential administration, a comprehensive national plan for stunting with significant budgetary discretion and executive authority was put in place (The Hambre Cero/ Zero Hunger initiative and its subsequent iterations)..$^{10} 11$ Guatemala is now ranked first in the world on the Hunger and Nutrition Commitment Index. ${ }^{12}$

This political evolution within Guatemala represents an opportunity to study multisectorial interventions for child stunting and to evaluate the public health impact of ambitious national policies. To this end, we conducted a scoping review of stunting research in Guatemala from 2000 to 2018, spanning the period including the Scaling Up Nutrition standards and new national strategies. In particular, we summarised new thematic directions and evidence for nutrition-sensitive and nutrition-specific interventions emerging within this time frame. ${ }^{13}$
METHODS

\section{Search and inclusion strategy}

We searched PubMed, Web of Science and PsycINFO databases. Our PubMed search string was: '(nutrition OR malnutrition OR stunting OR underweight OR 'iron deficiency anemia' OR 'low birth weight' OR 'maternal nutrition' OR autonomy OR 'thousand days' OR diversity OR productivity OR agriculture OR 'behavior change' OR sanitation OR 'clean water' OR 'WASH' OR 'maternal nutrition') AND Guatemala.' Similar search strategies were used for other databases. Eligible articles were published in English or Spanish between 1 January 2000 and 31 December 2018. All study designs and formats were included. At the stage of content review, we excluded meeting abstracts, articles not including data from Guatemala, and articles which did not explicitly discuss stunting or report on length-for-age and related outcomes. In addition, to allow for the inclusion of grey literature published in Spanish-especially Guatemalan university theses-we searched Google Scholar using the keywords 'desnutrición crónica' and 'Guatemala'. Finally, we manually reviewed the reference lists of included articles to identify additional resources, especially Spanishlanguage grey literature.

\section{Data extraction and synthesis}

We collated candidate articles in a spreadsheet, recording the study location or primary data source, study design and thematic areas, and a summary of findings. Given the predominance of stunting in Guatemala's indigenous Maya population, we also noted whether studies reported on or disaggregated outcomes by ethnicity. Our final classification taxonomy is given in the online supplementary table 1 . Titles were screened by two authors for eligibility, followed by a full-text review by two authors. Areas of disagreement were resolved by a third author. Articles eligible for inclusion after the full-text review are detailed in the online supplementary table 2 .

\section{Statistical analysis}

Statistical analysis was performed using STATA V.13. Frequencies from the thematic analysis were summarised using percentages. Changes in the proportion of articles reporting on important themes (eg, disaggregating data by ethnicity and studying priority areas) before and after the implementation of Guatemala's national stunting plan in 2012 were assessed using the $\chi^{2}$ test.

\section{Patient and public involvement}

As a scoping review of existing literature, patients and the public were not involved in the design, conduct, reporting or dissemination of this work. This review is, however, formative research toward new initiatives we and collaborators are developing to promote the public awareness of nutrition research in Guatemala. 

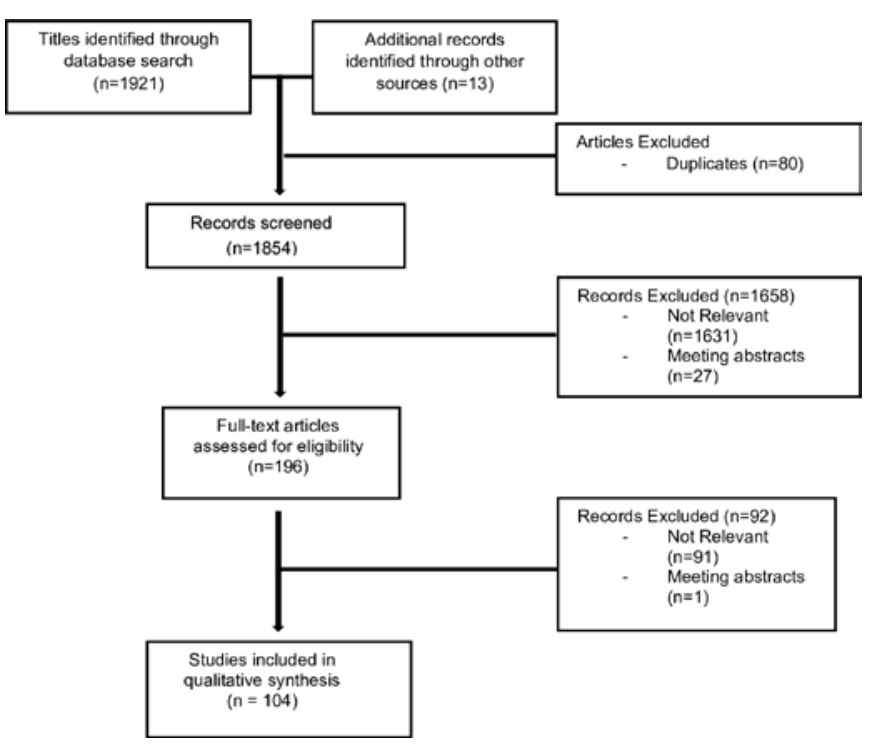

Figure 2 Flow diagram depicting results of the literature search and review procedure.

\section{RESULTS}

\section{Results of the literature screen}

We identified a total of 1934 articles through database searches, grey literature sources and reference lists (figure 2). Of these, 1738 were excluded prior to full-text review (80 duplicates, 27 meeting abstracts and 1631 not relevant). After full-text review, an additional 92 articles were excluded (1 meeting abstract, 91 not relevant), leaving 104 articles for the qualitative synthesis.

We oriented our thematic analysis around the national transition toward a comprehensive, multisectoral plan to combat stunting begun in 2012. ${ }^{14}$ Aligned with the Scaling up Nutrition framework, this plan calls for collaborative changes in public and private responses to malnutrition and for a focus on evidence-based interventions within the window from conception through 2 years of postnatal life (box 1). ${ }^{11}$ The framework recognises that successful initiatives will be multilevel and that new scholarship to design approaches that include both nutrition-specific (eg, micronutrient supplementation) and nutrition-sensitive (eg, agriculture) interventions is needed (online supplementary table 3 ).${ }^{13}$ The academy and other research-focused members of civil society are

\section{Box 1 Ten evidence-based priority areas included in} Guatemala's national stunting plan

- Support maternal breastfeeding.

- Improve complementary feeding after 6 months of age.

Improve hygiene knowledge and practices, including handwashing.

Vitamin A supplementation.

Zinc supplementation during acute diarrhoeal illness.

- Multiple micronutrient powder supplementation.

Deworming and vaccination.

Iron and folic acid supplementation for pregnant women.

Iodisation of salt.

Micronutrient fortification of basic foodstuffs. charged with leading implementation science efforts to evaluate effective initiatives both within government and private-sector efforts. ${ }^{15}$

\section{Summary of data sources and growth in the literature}

Beginning in 2012 (the start of a comprehensive national stunting plan), there was an important increase in the volume of articles on stunting. Of the 104 articles in our review, $38(37 \%)$ were published in 2000-2011 (mean 3.2 articles/year), whereas $66(63 \%)$ were published in 2012-2018 (mean 9.4 articles/year).

Given the growth in the literature on stunting post2012, we sought to determine if that growth stemmed from the generation of new datasets. A significant number of publications were from already-existing study cohorts. For example, manuscripts drawn from the INCAP Study represented $34 \%$ of all articles (table 1). Although an invaluable cohort study which has generated important insights into stunting, ${ }^{4-6}$ the contemporary members of the INCAP cohort are non-indigenous, middle-class and periurban dwelling-far removed from the policy priorities of the current national agenda. In addition, a number of publications were re-analyses of populationlevel surveys, including Demographic and Health Surveys $(8 \%)$ and National Standards of Living Surveys (7\%). In total, however, there was a significant increase in articles generating new study-specific data from 2000-2011 to $2012-2018$ (34\% vs $61 \%, \chi^{2}$ test, $\left.p=0.01\right)$. In addition, the proportion of studies disaggregating data by indigenous ethnicity increased from 2000-2011 to 2012-2018 (26\% vs $71 \%, \chi^{2}$ test, $\left.\mathrm{p}<0.001\right)$.

\section{Summary of trends in research focus}

Given national calls to prioritise multisectorial interventions for stunting and evaluate the implementation characteristics of stunting programme, we grouped articles into four major study designs: observational studies, implementation science, single-level and multilevel interventions (figure 3). In both 2000-2011 and 2012-2018, most studies were observational $(61 \%$ and $71 \%$, respectively). A small proportion of studies, $8 \%$ in 2000-2011 and $9 \%$ in 2012-2018, evaluated the implementation of programming. No studies of multilevel interventions were published before 2012 and only 4 (6\%) after. The proportion of single-level interventions fell from $24 \%$ to 6\% from 2000-2011 to 2012-2018. In total, the proportion of all implementation and intervention studies was $34 \%$ from 2000 to 2011 and $18 \%$ from 2012 to $2018\left(\chi^{2}\right.$ test, $\mathrm{p}=0.07)$. Finally, we also classified articles based on whether they included priority areas in Guatemala's national stunting plan (see box 1). In 2000-2011, 53\% of articles studied at least one of these areas; this proportion was not statistically different from that in 2012-2018 $\left(61 \% ; \chi^{2}\right.$ test, $\left.\mathrm{p}=0.43\right)$.

\section{Summary of intervention studies}

We summarised studies reporting interventions (table 2). There were 17 intervention studies published between 
Table 1 Selected primary data sources/cohorts and resulting publications on stunting in Guatemala

\begin{tabular}{|c|c|c|c|}
\hline Source & $\begin{array}{l}\text { Publications, } \\
\text { 2000-2018, n }\end{array}$ & $\begin{array}{l}\text { Years of data } \\
\text { collection }\end{array}$ & Description \\
\hline $\begin{array}{l}\text { Demographic and } \\
\text { Health Surveys }{ }^{40}\end{array}$ & 8 & $\begin{array}{l}1987,1995,1998- \\
999,2002,2008- \\
2009,2014-2015\end{array}$ & $\begin{array}{l}\text { Representative, population-based sampling using } \\
\text { standardised questions and indicators permitting cross- } \\
\text { country comparisons on important topics, including } \\
\text { household composition, fertility and family planning, } \\
\text { maternal and child health indicators, and child growth and } \\
\text { nutrition }\end{array}$ \\
\hline INCAP Study ${ }^{3}$ & 35 & $\begin{array}{l}1969-1977,1988- \\
1989,1991-1996 \\
1996-1999,1997- \\
1999,2002-2004 \\
2005-2007\end{array}$ & $\begin{array}{l}\text { A cluster-randomised study of the effect of early } \\
\text { complementary feeding and health services for pregnant } \\
\text { and lactating women and children from birth to } 7 \text { years } \\
\text { of age, carried out in four villages in eastern Guatemala } \\
\text { in 1969-1977, with subsequent multigenerational follow- } \\
\text { up of the cohort, yielding insights into the impact of } \\
\text { complementary feeding on growth and long-term outcomes, } \\
\text { such as economic productivity, schooling and non- } \\
\text { communicable diseases }\end{array}$ \\
\hline $\begin{array}{l}\text { Global Network } \\
\text { for Women's and } \\
\text { Children's Health } \\
\text { Research }\end{array}$ & 5 & 2008-present & $\begin{array}{l}\text { Funded through a public-private partnership between the } \\
\text { National Institutes of Health of the United States and the Bill } \\
\text { \& Melinda Gates Foundation, a multicountry collaborative } \\
\text { which includes a maternal newborn health registry, as well } \\
\text { as multiple clinical trials }\end{array}$ \\
\hline $\begin{array}{l}\text { National Standards of } \\
\text { Living Survey }{ }^{42}\end{array}$ & 7 & $\begin{array}{l}2000,2006,2011, \\
2014\end{array}$ & $\begin{array}{l}\text { A representative, population-based survey run by the } \\
\text { Guatemalan Institute of Statistics, which includes data on } \\
\text { socioeconomic indicators, poverty, work conditions, as well } \\
\text { as child growth and other health indicators }\end{array}$ \\
\hline $\begin{array}{l}\text { Universidad del } \\
\text { Valle de Guatemala } \\
\text { Longitudinal Study }^{43}\end{array}$ & 1 & 1953-1999 & $\begin{array}{l}\text { The Universidad del Valle de Guatemala Longitudinal Study } \\
\text { was a study of human growth and intelligence that enrolled } \\
\text { children from seven urban and two rural schools, with } \\
\text { regular measurements. The data are partly cross-sectional } \\
\text { and partly longitudinal and are still only partially collated but } \\
\text { may include observations on }>130000 \text { children }\end{array}$ \\
\hline
\end{tabular}

INCAP, Institute of Nutrition of Central America and Panama.

2000 and 2018. Of these, many were studies of the INCAP cohort, reporting long-term outcomes in adults who had participated as children in the previous 1960s supplementation intervention $(47 \%, \mathrm{n}=8)$. These included reports on positive long-term educational, cognitive and economic outcomes. ${ }^{16-18}$ Two others examined the effects of early supplementation on cardiovascular disease risk factors. ${ }^{19}$ Two final INCAP studies reported on the

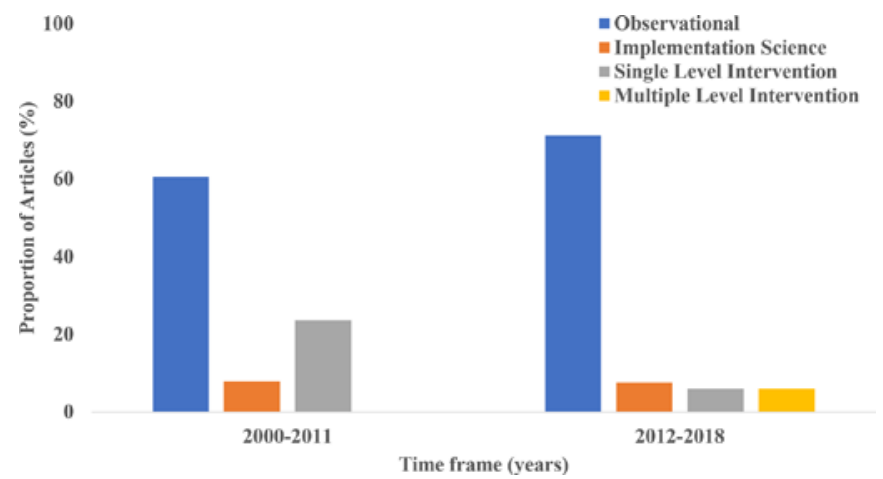

Figure 3 Distribution of major study types in the literature on stunting in Guatemala, 2000-2011 and 2012-2018. intergenerational impact of the intervention, finding that children born to women who had been supplemented themselves as children had improved growth. ${ }^{20}$

In addition to the INCAP publications, the remaining intervention studies were also primarily single-level dietary supplementation studies. Begin et al evaluated the protein and micronutrient composition of a fortified cereal product in an individually randomised trial, finding no significant difference in stunting for four different compositions. ${ }^{21}$ Mazariegos et al found no impact on stunting in infants of supplementation with zinc or phytate-reduced corn. ${ }^{22}$ Krebs $e t$ al and Newman et al reported outcomes from a Global Network for Women's and Children's Health Research study, showing no impact on stunting for dietary supplementation with meat or a fortified cereal product. ${ }^{23}$ One final study showed improved stunting in children supplemented with a fortified cereal product but was not controlled. ${ }^{24}$

Using a taxonomy previously described to classify determinants of nutrition (online supplementary table 3), we found two studies that involved interventions on more than one nutrition determinant. ${ }^{25}$ Both included dietary 
Table 2 Summary of articles describing stunting-related interventions in Guatemala 2000-2018

\begin{tabular}{|c|c|c|c|}
\hline Study & Design & $\begin{array}{l}\text { Nutrition specific } \\
\text { Interventions* }\end{array}$ & Brief summary \\
\hline Li et $a l^{16}$ & $\begin{array}{l}\text { Cluster randomised, single- } \\
\text { level }\end{array}$ & $\begin{array}{l}\text { Dietary } \\
\text { supplementation }\end{array}$ & $\begin{array}{l}\text { INCAP Study publication, reporting educational } \\
\text { attainment outcomes for adults who had previously } \\
\text { participated in the prior childhood supplementation trial }\end{array}$ \\
\hline Stein et $a l^{20}$ & $\begin{array}{l}\text { Cluster randomised, single- } \\
\text { level }\end{array}$ & $\begin{array}{l}\text { Dietary } \\
\text { supplementation }\end{array}$ & $\begin{array}{l}\text { INCAP Study publication, reporting the } \\
\text { intergenerational impact of prior childhood } \\
\text { supplementation trial on birth length }\end{array}$ \\
\hline Conlisk et $a l^{19}$ & $\begin{array}{l}\text { Cluster randomised, single- } \\
\text { level }\end{array}$ & $\begin{array}{l}\text { Dietary } \\
\text { supplementation }\end{array}$ & $\begin{array}{l}\text { INCAP Study publication, reporting reduced fasting } \\
\text { glucose among men who had participated in the prior } \\
\text { childhood supplementation trial on birth length. Among } \\
\text { supplemented women, the effect was only seen among } \\
\text { those born thin }\end{array}$ \\
\hline Stein et $a l^{44}$ & $\begin{array}{l}\text { Cluster randomised, single- } \\
\text { level }\end{array}$ & $\begin{array}{l}\text { Dietary } \\
\text { supplementation }\end{array}$ & $\begin{array}{l}\text { INCAP Study publication, reporting improvement in } \\
\text { some adult cardiovascular risk factors and no evidence } \\
\text { for increased cardiovascular risk among those who had } \\
\text { participated in the prior childhood supplementation trial }\end{array}$ \\
\hline Begin et $a l^{21}$ & $\begin{array}{l}\text { Individually randomised, } \\
\text { single-level }\end{array}$ & $\begin{array}{l}\text { Dietary } \\
\text { supplementation }\end{array}$ & $\begin{array}{l}\text { Reports no differential impact on stunting for four } \\
\text { different supplemental foods, containing either bovine } \\
\text { serum concentrate or whey protein concentrate, with or } \\
\text { without micronutrients }\end{array}$ \\
\hline $\begin{array}{l}\text { Hoddinott et } \\
\text { al }\end{array}$ & $\begin{array}{l}\text { Cluster randomised, single- } \\
\text { level }\end{array}$ & $\begin{array}{l}\text { Dietary } \\
\text { supplementation }\end{array}$ & $\begin{array}{l}\text { INCAP Study publication, reporting the positive } \\
\text { economic impact on adult income for those who had } \\
\text { participated in the prior childhood supplementation trial }\end{array}$ \\
\hline Stein et $a l^{45}$ & $\begin{array}{l}\text { Cluster randomised, single- } \\
\text { level }\end{array}$ & $\begin{array}{l}\text { Dietary } \\
\text { supplementation }\end{array}$ & $\begin{array}{l}\text { INCAP Study publication, reporting the positive impact } \\
\text { on reading comprehension and abstract reasoning } \\
\text { among adults who had participated in the prior } \\
\text { childhood supplementation trial }\end{array}$ \\
\hline Maluccio et $a l^{18}$ & $\begin{array}{l}\text { Cluster randomised, single- } \\
\text { level }\end{array}$ & $\begin{array}{l}\text { Dietary } \\
\text { supplementation }\end{array}$ & $\begin{array}{l}\text { INCAP Study publication, reporting improved grade } \\
\text { completion and reading and nonverbal cognition } \\
\text { among adults who had participated in the prior } \\
\text { childhood supplementation trial }\end{array}$ \\
\hline Behrman et al ${ }^{46}$ & $\begin{array}{l}\text { Cluster randomised, single- } \\
\text { level }\end{array}$ & $\begin{array}{l}\text { Dietary } \\
\text { supplementation }\end{array}$ & $\begin{array}{l}\text { INCAP Study publication, reporting improvements in } \\
\text { offspring growth, including stunting, for women who } \\
\text { had participated in the prior childhood supplementation } \\
\text { trial }\end{array}$ \\
\hline $\begin{array}{l}\text { Mazariegos et } \\
a l^{22}\end{array}$ & $\begin{array}{l}\text { Individually randomised, } \\
\text { single-level }\end{array}$ & $\begin{array}{l}\text { Dietary } \\
\text { supplementation }\end{array}$ & $\begin{array}{l}\text { In a rural indigenous population, reports lack of impact } \\
\text { on stunting of either zinc supplementation or low- } \\
\text { phytate corn }\end{array}$ \\
\hline Krebs et $a l^{23}$ & $\begin{array}{l}\text { Cluster randomised, single- } \\
\text { level }\end{array}$ & $\begin{array}{l}\text { Dietary } \\
\text { supplementation }\end{array}$ & $\begin{array}{l}\text { A Global Network for Women's and Children's } \\
\text { Health Research multi-country study, including rural } \\
\text { Guatemala, showing no impact of meat or fortified } \\
\text { cereal supplementation on stunting }\end{array}$ \\
\hline Newman et $a l^{47}$ & $\begin{array}{l}\text { Cluster randomised, single- } \\
\text { level }\end{array}$ & $\begin{array}{l}\text { Dietary } \\
\text { supplementation }\end{array}$ & $\begin{array}{l}\text { A Global Network for Women's and Children's Health } \\
\text { Research study. Exploration of between-group } \\
\text { differences from the negative Krebs et } \mathrm{al}^{23} \text { study, } \\
\text { showing that between-group variation or issues with } \\
\text { protocol fidelity did not explain the lack of intervention } \\
\text { impact on stunting }\end{array}$ \\
\hline Jensen et $\left.a\right|^{26}$ & $\begin{array}{l}\text { Cluster randomised, } \\
\text { multiple-level }\end{array}$ & $\begin{array}{l}\text { Dietary } \\
\text { supplementation, } \\
\text { complementary } \\
\text { feeding practices }\end{array}$ & $\begin{array}{l}\text { Multi-level intervention, including food supplementation } \\
\text { and behaviour change interventions around } \\
\text { complementary feeding practices, showing } \\
\text { improvements in household dietary diversity }\end{array}$ \\
\hline Palacios $^{24}$ & $\begin{array}{l}\text { Quasi-experimental, single- } \\
\text { level }\end{array}$ & $\begin{array}{l}\text { Dietary } \\
\text { supplementation }\end{array}$ & $\begin{array}{l}\text { Prenalysis and postanalysis showing improvements in } \\
\text { the linear growth of a fortified cereal product }\end{array}$ \\
\hline
\end{tabular}


Table 2 Continued

\begin{tabular}{|c|c|c|c|}
\hline Study & Design & $\begin{array}{l}\text { Nutrition specific } \\
\text { Interventions* }\end{array}$ & Brief summary \\
\hline Martinez et $\left.a\right|^{27}$ & $\begin{array}{l}\text { Individually-randomised, } \\
\text { multiple-level }\end{array}$ & $\begin{array}{l}\text { Dietary } \\
\text { supplementation, } \\
\text { complementary } \\
\text { feeding practices }\end{array}$ & $\begin{array}{l}\text { Multiple-level intervention, including food } \\
\text { supplementation and behaviour change interventions } \\
\text { around complementary feeding practices, improved } \\
\text { diet quality compared with a single-level food } \\
\text { supplementation intervention }\end{array}$ \\
\hline Martinez et $a l^{28}$ & $\begin{array}{l}\text { Individually-randomised, } \\
\text { multiple-level }\end{array}$ & $\begin{array}{l}\text { Dietary } \\
\text { supplementation, } \\
\text { complementary } \\
\text { feeding practices }\end{array}$ & $\begin{array}{l}\text { Reports significantly improved developmental } \\
\text { outcomes for stunted children from the Martinez } \\
(2018)^{27} \text { trial with, however, no significant difference } \\
\text { between the multilevel and single-level arms }\end{array}$ \\
\hline Olney et $a l^{29}$ & $\begin{array}{l}\text { Cluster randomised, } \\
\text { multiple-level }\end{array}$ & $\begin{array}{l}\text { Dietary } \\
\text { supplementation, } \\
\text { complementary } \\
\text { feeding practices }\end{array}$ & $\begin{array}{l}\text { Reports outcomes data from the same population } \\
\text { studied in Jensen. }{ }^{26} \text { Improvements in both early } \\
\text { ( } 1 \text { month) and later ( } 24 \text { months) stunting, especially } \\
\text { in clusters which received both family food rations } \\
\text { and fortified cereal or multiple micronutrient powder } \\
\text { targeted to the child }\end{array}$ \\
\hline
\end{tabular}

${ }^{*}$ No studies were found evaluating any nutrition-sensitive interventions, and so a column for this is not included in the table. INCAP, Institute of Nutrition of Central America and Panama.

supplementation with the addition of complementary feeding interventions. ${ }^{26-29}$ The first was a large, clusterrandomised trial evaluating combinations of family food rations, fortified cereal or micronutrient powder supplements, and behaviour change around complementary feeding practices. The greatest improvements were seen among clusters that received both family food rations and infant supplements. ${ }^{29}$ In addition, the cluster which received the behaviour change intervention showed improvements in diet diversity, including for food groups not provided in the ration. ${ }^{26}$ The second study was a small individually randomised trial that provided a food ration and micronutrient supplement to both control and intervention groups and a complementary feeding behaviour change intervention to the intervention group. For families receiving the behaviour change intervention, diet diversity improved, including for food groups not provided in the food ration, although improvements in growth were not significant. ${ }^{27}$ This study also measured developmental outcomes, finding improvements in development in both arms. ${ }^{28}$

Finally, given the guidance provided by the Scaling up Nutrition framework and Guatemala's new policy interest in interventions targeting both immediate (nutritionspecific) and underlying (nutrition-sensitive) determinants of child growth, ${ }^{11} 1325$ we classified all intervention studies by inclusion of nutrition-specific or nutritionsensitive interventions. As noted above, we found only two studies intervening on multiple determinants of growth, and we found no studies evaluating any nutritionsensitive interventions (table 2).

\section{Summary of implementation science evaluations}

Finally, we summarised articles dealing with implementation analysis around stunting interventions (table 3). In total, we identified nine implementation studies published between 2000 and 2018. Bennett conducted an ethnographic study of child nutrition in a rural Maya town, concluding that differences in many nutritionspecific targets-such as behaviours around complementary feedings-do not correlate well with improvements in stunting. Instead, she noted the 'syndemic' nature of stunting, highlighting the need to target root social causes, including nutrition-sensitive components. ${ }^{30}$ Fort et al evaluated the impact of a new "inclusive health" primary care initiative. They found that the model improved health equity and healthcare utilisation but that stunting and wasting remained very high. Similar to Bennett, they concluded that multisectorial social programme-not just health system strengthening-are needed for stunting. ${ }^{31}$

Three additional studies were qualitative investigations of the implementation of child nutrition programme. Schooley and Morales examined Project Concern International's group-based Positive Deviance approach for caregivers of malnourished children. They found that the method was less effective in Guatemala than in other countries where it had been implemented, in part because of difficulties engaging both male and female caregivers. ${ }^{32}$ Chary et al found that, in rural communities, child malnutrition was so prevalent that it became 'normalised' with low awareness that it was a significant health problem. ${ }^{33}$ Overcoming this required consensus building and conscientisation to mobilise community resources. Finally, Davis et al documented barriers to implementing ready-to-use therapeutic foods for stunting. They found an important barrier was conflicting public health messages; for example, mothers were reluctant to feed children because of misunderstandings around messaging on the duration of exclusive breastfeeding. ${ }^{34}$ 
Table 3 Summary of articles engaging implementation science themes around stunting and stunting-related interventions in Guatemala 2000-2018

\begin{tabular}{lll}
\hline Study & Design & Brief summary \\
\hline Bennett $^{30}$ & Dissertation & $\begin{array}{l}\text { Uses the theoretical framework of a 'syndemic' to examine stunting in a rural Maya } \\
\text { community. Finds that improvements in classic intervention targets, like maternal } \\
\text { education, do not correlate well with improvements in stunting. Highlights the need } \\
\text { to also address geographic isolation, environmental and WASH infrastructure, and } \\
\text { inadequacy of subsistence agriculture to provide food security }\end{array}$ \\
$\begin{array}{l}\text { Schooley and } \\
\text { Morales }^{32}\end{array}$ & $\begin{array}{l}\text { Qualitative } \\
\text { Reviews Project Concern International use of group-based Positive Deviance } \\
\text { approaches with indigenous families to improve child growth and nutrition. The impact } \\
\text { of the methodology was less marked than that seen in other countries, and this was in } \\
\text { part explained by difficulty engaging both caregivers and by men not being supportive } \\
\text { of their wives' participation }\end{array}$
\end{tabular}

\begin{tabular}{|c|c|c|}
\hline Fort et $a^{31}$ & Dissertation & $\begin{array}{l}\text { Examines the implementation of an innovative primary care model focused on inclusive } \\
\text { and culturally appropriate care in a rural indigenous health district. Finds that the model } \\
\text { improved equity in access to care, healthcare utilisation and vaccination. Both stunting } \\
\text { and wasting remained very high, however, the authors emphasised that multisectorial } \\
\text { social programme and not just health system strengthening are needed }\end{array}$ \\
\hline Pelletier et $\left.a\right|^{35}$ & Qualitative & $\begin{array}{l}\text { Reviews the effectiveness of national efforts to scale up nutrition policy. Conclusions } \\
\text { include that high-level political attention to stunting is not sufficient to achieve change, } \\
\text { which requires sustained actions from mid-level actors and entrepreneurs and better } \\
\text { investments in frontline organisational capacity }\end{array}$ \\
\hline
\end{tabular}

$\begin{array}{ll}\text { Chary et }\left.a\right|^{33} & \text { Qualitative } \\ \text { Paz }^{37} & \text { Mixed methods }\end{array}$

Explores community and caregiver perceptions of stunting in an indigenous community. Child malnutrition is highly prevalent and therefore 'normalised' with low awareness that it is a significant health problem, requiring significant consensus building in order to mobilise community resources

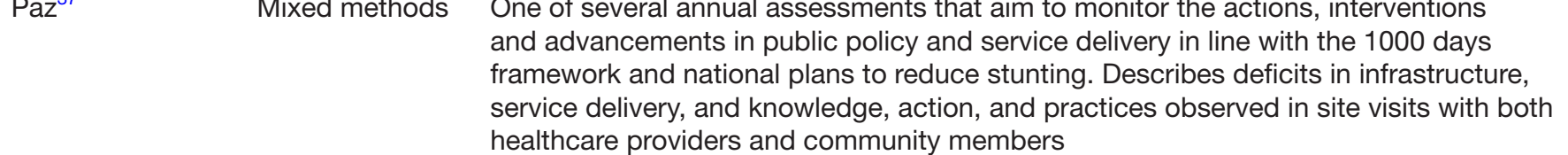

$\begin{array}{ll}\text { Davis et } \mathrm{al}^{34} \quad \text { Qualitative } & \begin{array}{l}\text { Documents implementation barriers to community-based supplementary feeding } \\ \text { for stunting, including misunderstandings related to messaging around exclusive } \\ \text { breastfeeding and how these conflict with messaging around the need to provide timely } \\ \text { complementary feeding, as well as sharing of supplements among family members, } \\ \text { and the need to standardise messaging and therapeutic benefit communicated by staff } \\ \text { to beneficiaries }\end{array} \\ & \begin{array}{l}\text { Analysis of the Food Insecurity and Malnutrition in Guatemala Project that aimed to } \\ \text { evaluate food security and nutrition policies to advocate for effective policies around } \\ \text { Pulgar }{ }^{36}\end{array} \\ \begin{array}{l}\text { stunting. Primarily concludes that there is a need to strengthen national research } \\ \text { efforts around outcomes, update technical recommendations based on newly available } \\ \text { nutritional and food security data, and strengthen private and university sector } \\ \text { collaborations with the government }\end{array}\end{array}$

WASH, Water, Sanitation and Hygiene.

Three final studies examined policy documents around child nutrition. Pelletier et al in a multi-country review including Guatemala examined the effectiveness of national strategies to scale up nutrition policy. They concluded that political will and legislation was often undermined when mid-level actors were not empowered to enact and adapt policy as appropriate and when the frontline organisational capacity to deliver new initiatives was limited. ${ }^{35}$ Pulgar conducted a similar analysis, concluding that a lack of national research and technical capacity limited the ability to innovate and evaluate, and calling for improved academic and public-private sector collaborations. ${ }^{36}$ Finally, Paz conducted a systematic audit of frontline public health facility capacity and quality of care, documenting the breaches between national policy and local reality and calling for better investments in frontline personnel and infrastructure. ${ }^{37}$

\section{DISCUSSION}

Guatemala has the highest prevalence of stunting in Central America, and one of the highest in the world (figure 1). Guatemala has also served as a major site for child nutrition research, since the famous INCAP cohort study in the 1960 s to the present day. ${ }^{3}$ Historically, the political will to address stunting in Guatemala has been 
low. However, since 2012, the Government of Guatemala has called for comprehensive approaches incorporating both nutrition-specific and nutrition-sensitive interventions; implementation science; prioritisation of rural populations; and stronger academic partnerships. ${ }^{11}$ Here, we conducted a systematic search and scoping review of the literature on stunting in Guatemala from 2000 to 2018 to investigate the impact these policy trends have had.

Taking 2012 as an inflection point, we found several positive signs that the field has responded to calls for innovation on stunting. For example, the volume of articles on stunting rose more than threefold. Similarly, there was a shift toward new data on prioritised populations, and the number of studies reporting data disaggregated by ethnicity rose. At the same time, however, most studies remained observational in nature, with no change in the proportion of intervention or implementation science studies or in priority topical areas (box 1, figure 3 ).

In terms of interventions (table 2), prior to 2012, most studies were follow-up analyses of adults in the INCAP cohort who had received intervention decades prior. Post-2012, there were several new interventions studied, including three randomised clinical trials that evaluated different dietary supplementation or complementary feeding approaches. ${ }^{23} 2729$ However, there was a clear lack of multilevel interventions, with only two studies in the entire period 2000-2018 addressing more than one determinant of child growth. Furthermore, we did not find studies evaluating any nutrition-sensitive intervention (table 2). This deficiency was reinforced by findings from the few implementation assessments, which highlighted the marginal efficacy of health systems interventions and called for broader-based strategies to address the underlying determinants of child growth. ${ }^{30} 313537$

In conclusion, our review highlights the equivocal responsiveness of the academic community and the literature to important new national priorities in Guatemala around child stunting since 2012. Most studies remain observational and the call for stronger academic involvement in shaping and evaluating policy has not been fully realised. In particular, there is a need for studies that follow the Scaling up Nutrition call to design and evaluate multicomponent interventions and, particularly, interventions that target nutrition-sensitive domains. Furthermore, there is a need for more implementationfocused research which evaluates what works, what does not work and why. Our review of these findings in the published international literature is complementary to a recent critical review of stunting programming in Guatemala, which also highlights the need for comprehensive efforts, including efforts to address structural and not just proximal determinants of the problem. ${ }^{38}$

Our review has important limitations. Although we extensively searched the publication databases, which included both articles published in Spanish and English, we know that many experiences within Guatemala are conducted by local health authorities, community groups, and nongovernmental organisations outside the academy. These experiences are rarely codified and disseminated. In addition, the grey literature published in Spanish is not well indexed. We identified many important grey literature Spanish publications through supplementary searches of reference lists and university theses in Google Scholar, however these searches are undoubtedly not comprehensive. Taken together, these observations call for efforts to forge stronger academic collaborations with private-sector and public-sector implementers so that these experiences can be better indexed and more quickly disseminated. In addition, a systematic mapping of implementing organisations and informal programmatic collaborations is badly needed. We are in the early stages of conducting this mapping exercise, in collaboration with Guatemala's Secretariat for Nutrition and Food Security, to address these deficiencies. ${ }^{39}$

Acknowledgements The authors thank research subjects and clinical staff at Maya Health Alliance for inspiring their interest in this important topic.

Contributors AC: conceived the study, designed the search strategy, extracted data from articles, and revised the manuscript. GA: extracted data from articles and revised the manuscript. TDV: conducted the searches and extracted data from articles. PR: conceived the study, resolved disagreements during review, and wrote the first draft of the manuscript.

Funding The authors have not declared a specific grant for this research from any funding agency in the public, commercial or not-for-profit sectors.

Competing interests None declared.

Patient consent for publication Not required.

Provenance and peer review Not commissioned; externally peer reviewed.

Data availability statement All data relevant to the study are included in the article or uploaded as supplementary information.

Open access This is an open access article distributed in accordance with the Creative Commons Attribution Non Commercial (CC BY-NC 4.0) license, which permits others to distribute, remix, adapt, build upon this work non-commercially, and license their derivative works on different terms, provided the original work is properly cited, appropriate credit is given, any changes made indicated, and the use is non-commercial. See: http://creativecommons.org/licenses/by-nc/4.0/.

ORCID iD

Peter Rohloff http://orcid.org/0000-0001-7274-8315

\section{REFERENCES}

1 Black RE, Victora CG, Walker SP, et al. Maternal and child undernutrition and overweight in low-income and middle-income countries. The Lancet 2013;382:427-51.

2 World Health Organization Global database on child growth and malnutrition. Available: http://apps.who.int/nutgrowthdb/database/ search [Accessed Aug 2019].

3 Ramirez-Zea M, Melgar P, Rivera JA. INCAP Oriente longitudinal study: 40 years of history and legacy. J Nutr 2010;140:397-401.

4 Scrimshaw NS. Historical concepts of interactions, synergism and antagonism between nutrition and infection. J Nutr 2003;133:316S-21.

5 Scrimshaw NS. Food and nutrition policy. Available: http://archive. unu.edu/unupress/food/8F011e/8F011E04.htm [Accessed Jun 2019].

6 Martorell R, de Romaña DL. Components of successful staple food fortification programs: lessons from Latin America. Food Nutr Bull 2017;38:384-404.

7 de Onis M, Garza C, Victora CG, et al. The who multicentre growth reference study: planning, study design, and methodology. Food Nutr Bull 2013;25.

8 Alianza por la Nutrición, Agencia de los Estados Unidos para el Desarrollo Internacional. Guía metodológica para la implementación de acciones a nivel comunitario para reducir la desnutrición 
crónica infantil y generar sostenibilidad de la seguridad alimentaria nutricional, 2014.

10 Lovon M. Evolución de las estrategias de reducción de la desnutrición crónica en Guatemala. Available: http://www.siinsan. gob.gt/siinsan/wp-content/uploads/Guatemala-Case-Study-Reportsp-FINAL-WEB-1.pdf [Accessed Jun 2019].

10 Hamel R. Tracking promises: analyzing the impact of feed the future in Guatemala. Washington, DC: Center for Strategic and International Studies, 2017.

11 Scaling up nutrition: a framework for action. Available: https:// scalingupnutrition.org/wp-content/uploads/2013/05/SUN Framework.pdf [Accessed Jun 2019].

$12 \mathrm{HANCl}$ global hunger and nutrition commitment index. Available: http://www.hancindex.org/hanci/ [Accessed 7 Aug 2019].

13 Hossain M, Choudhury N, Adib Binte Abdullah K, Adib K, et al. Evidence-Based approaches to childhood stunting in low and middle income countries: a systematic review. Arch Dis Child 2017;102:903-9.

14 Gobierno de Guatemala. Pacto hambre cero. Available: https:// extranet.who.int/nutrition/gina/sites/default/files/GUA\%202012\% 20Pacto\%20Hambre\%20Cero\%20Guatemala.pdf [Accessed Feb 2019].

15 Secretaría de Seguridad Alimentaria y Nutricional. Estrategia nacional para La prevención de la desnutrición crónica 2016-2020. 2016. Available: http://www.sesan.gob.gt/wordpress/wp-content/ uploads/2017/07/Estrategia-para-la-Prevencion-de-la-DesnutricionCronica.pdf [Accessed Jan 2019].

16 Li H, Barnhart HX, Stein AD, et al. Effects of early childhood supplementation on the educational achievement of women. Pediatrics 2003;112:1156-62.

17 Hoddinott J, Maluccio JA, Behrman JR, et al. Effect of a nutrition intervention during early childhood on economic productivity in Guatemalan adults. The Lancet 2008;371:411-6.

18 Maluccio JA, Hoddinott J, Behrman JR, et al. The impact of improving nutrition during early childhood on education among Guatemalan adults. Econ J 2009;119:734-63.

19 Conlisk AJ, Barnhart HX, Martorell R, et al. Maternal and child nutritional supplementation are inversely associated with fasting plasma glucose concentration in young Guatemalan adults. $J$ Nutr 2004;134:890-7.

20 Stein AD, Barnhart HX, Hickey M, et al. Prospective study of protein-energy supplementation early in life and of growth in the subsequent generation in Guatemala. Am J Clin Nutr 2003;78:162-7.

21 Bégin F, Santizo M-C, Peerson JM, et al. Effects of bovine serum concentrate, with or without supplemental micronutrients, on the growth, morbidity, and micronutrient status of young children in a low-income, peri-urban Guatemalan community. Eur J Clin Nutr 2008;62:39-50.

22 Mazariegos M, Hambidge KM, Westcott JE, et al. Neither a zinc supplement nor phytate-reduced maize nor their combination enhance growth of 6- to 12-month-old Guatemalan infants. J Nutr 2010;140:1041-8.

23 Krebs NF, Mazariegos M, Chomba E, et al. Randomized controlled trial of meat compared with multimicronutrient-fortified cereal in infants and toddlers with high stunting rates in diverse settings. Am $J$ Clin Nutr 2012;96:840-7.

24 Palacios AM, Villanueva LM, Cuy-Castellanos D, et al. Aceptabilidad de un atole fortificado con 21 micronutrientes e impacto en la salud y nutrición de niños menores de 6 años de edad en la Ciudad de Guatemala. Arch Latinoam Nutr 2017:67:15-22.

25 Ruel MT, Alderman H. Nutrition-sensitive interventions and programmes: how can they help to accelerate progress in improving maternal and child nutrition? The Lancet 2013;382:536-51.

26 Jensen ML, Frongillo EA, Leroy JL, et al. Participating in a food-assisted maternal and child nutrition and health program in rural Guatemala alters household dietary choices. $J$ Nutr 2016;146:1593-600

27 Martinez B, Webb MF, Gonzalez A, et al. Complementary feeding intervention on stunted Guatemalan children: a randomised controlled trial. Bmjpo 2018;2:e000213.
28 Martinez B, Cardona S, Rodas P, et al. Developmental outcomes of an individualised complementary feeding intervention for stunted children: a substudy from a larger randomised controlled trial in Guatemala. Bmjpo 2018;2:e000314.

29 Olney DK, Leroy J, Bliznashka L, et al. PROCOMIDA, a foodassisted maternal and child health and nutrition program, reduces child stunting in Guatemala: a cluster-randomized controlled intervention trial. J Nutr 2018;148:1493-505.

30 Bennett EM. Understanding childhood malnutrition in a Maya village in Guatemala: a syndemic perspective [dissertation]. Storrs, CT: University of Connecticut, 2009.

31 Fort MP, Grembowski D, Heagerty P, et al. Evaluation of a demonstration primary health care project in rural Guatemala: the influence of predisposing, enabling and need factors on immunization coverage, equitable use of health care services and application of treatment guidelines. Int Health 2012;4:220-8.

32 Schooley J, Morales L. Learning from the community to improve maternal-child health and nutrition: the positive Deviance/Hearth approach. J Midwifery Womens Health 2007;52:376-83.

33 Chary A, Messmer S, Sorenson E, et al. The normalization of childhood disease: an ethnographic study of child malnutrition in rural Guatemala. Hum Organ 2013;72:87-97.

34 Davis T, Fischer E, Rohloff P, et al. Chronic malnutrition, breastfeeding, and ready to use supplementary food in a Guatemalan Maya town. Hum Organ 2014;73:72-81.

35 Pelletier DL, Frongillo EA, Gervais S, et al. Nutrition agenda setting, policy formulation and implementation: lessons from the Mainstreaming Nutrition Initiative. Health Policy Plan 2012;27:19-31.

36 Pulgar D. Proyecto inseguridad alimentaria $Y$ desnutricion en Guatemala. Available: https://idl-bnc-idrc.dspacedirect.org/handle/ 10625/56354 [Accessed August 2019].

37 Paz V. Monitoreo de las acciones de la ventana de Los mil días. Guatemala City: Centro de Investigaciones Ecónomicas Nacionales, 2014.

38 Instituto de Investigación y Proyección sobre Ambiente Natural y Sociedad (larna). Análisis sistémico Y territorial de la seguridad alimentaria Y nutricional en Guatemala: consideraciones para mejorar prácticas Y políticas públicas. Editorial Cara Parens 2015;144

39 Cordón A, Asturias G, Pineda E, et al. Protocolo implementación mapeo de actores Conéctate Guate. Guatemala City: FUNDEGUA, 2019.

40 United States Agency for International Development. The DHS program demographic and health surveys. Available: https:// dhsprogram.com/What-We-Do/survey-search.cfm?pgtype=main\& SrvyTp=country\&ctry_id=15 [Accessed May 2019].

41 National Institutes of Health Eunice Kennedy Shriver National Institute of Child Health and Human Development. Global network for women's and children's health research. Available: https://www. nichd.nih.gov/research/supported/globalnetwork [Accessed May 2019]

42 Instituto Nacional de Estadística Guatemala. Encuesta nacional de condiciones de vida. Available: https://www.ine.gob.gt/index.php/ encuestas-de-hogares-y-personas/condiciones-de-vida [Accessed May 2019].

43 Varela-Silva MI, Bogin B, Sobral JAG, et al. Deep data science to prevent and treat growth faltering in Maya children. Eur J Clin Nutr 2016;70:679-80

44 Stein $A D$, Wang $M$, Ramirez-Zea $M$, et al. Exposure to a nutrition supplementation intervention in early childhood and risk factors for cardiovascular disease in adulthood: evidence from Guatemala. Am J Epidemiol 2006;164:1160-70.

45 Stein AD, Wang M, DiGirolamo A, et al. Nutritional supplementation in early childhood, schooling, and intellectual functioning in adulthood. Arch Pediatr Adolesc Med 2008;162:612-8.

46 Behrman JR, Calderon MC, Preston SH, et al. Nutritional supplementation in girls influences the growth of their children: prospective study in Guatemala. Am J Clin Nutr 2009;90:1372-9.

47 Newman JE, Garces A, Mazariegos M, et al. Theory-driven process evaluation of a complementary feeding trial in four countries. Health Educ Res 2014;29:297-305. 